\title{
A MERCANTILIZAÇÃO DO ESPAÇO URBANO AMAZÔNICO: O CASO DO BAR DO PARQUE EM BELÉM-PA.
}

Dan Rodrigues Levy ${ }^{*}$

\section{RESUMO}

Este artigo analisa a mercantilização do espaço urbano através da gentrificação, instrumento de "revitalização" de áreas degradadas que descaracteriza o uso, a arquitetura, e a memória da cidade, violando inclusive normas urbanísticas. Como cenário de análise, aborda-se o caso do Bar do Parque, em Belém, quiosque localizado no centro da cidade, de estilo Art Nouveau, símbolo da belle époque amazônica, que representa um espaço de deliberação política e de manifestações sociais e culturais da cidade. Conclui-se que o processo de gentrificação, quando influenciado pelo modelo urbano neoliberal, contribui para aprofundar o processo de segregação e fragmentação nas cidades.

Palavras-chave: Mercantilização do Espaço Urbano; Urbanismo Neoliberal; Gentrificação; Direito Urbanístico; Bar do Parque.

\section{COMMERCIALIZATION OF THE AMAZON URBAN SPACE: THE CASE OF BAR DO PARQUE IN BELÉM-PA}

\begin{abstract}
This article analyzes the commercialization of urban space through gentrification, an instrument of "revitalization" in degraded areas that deprives the use, architecture, and memory of the city, violating urban norms. As an analysis scenario, the case of Bar do Parque, in Belém, a kiosk located in downtown city, Art Nouveau style, symbol of the Amazon's belle époque, which represents a space for political deliberation and social and cultural manifestations of the city. It is concluded that the process of gentrification, when influenced by the neoliberal urban model, contributes to deepen the process of segregation and fragmentation in cities.
\end{abstract}

Key-words: Commercialization of Urban Space; Neoliberal Urbanism; Gentrification; Urban Law; Bar do Parque.

\section{INTRODUÇÃO}

O presente artigo tem como tema principal a análise da mercantilização do espaço urbano amazônico, frente a um modelo de urbanização que prioriza o capital neoliberal, acarretando consequências diversas para a cidade. Este modelo inaugura um novo conceito de cidade para os estudos urbanos: a cidade neoliberal, aquela na qual o espaço urbano é

\footnotetext{
* Doutor em Sociologia Urbana pela Universidade de Coimbra, Portugal, com ênfase na pesquisa sobre urbanização em São Paulo. Mestre em Direitos Humanos e Meio Ambiente pela Universidade Federal do Pará. Pós-graduado em Tutela dos Interesses Difusos, Coletivos e Individuais Homogêneos pela Universidade da Amazônia. Bacharel em Direito pelo Centro Universitário do Estado do Pará. Atualmente é Consultor Jurídico nas áreas de Direito Ambiental e Urbanístico e Professor de Direito da Escola Paulista de Política, Economia e Negócios da Universidade Federal de São Paulo (Unifesp/EPPEN). E-mail: danlevy82@ gmail.com.
} 
mercantilizado, a cidade é tratada como mercadoria, e só quem tem acesso aos direitos da cidade são aqueles que podem pagar pelos mesmos.

A justificativa para esta discussão é válida na medida em que este fenômeno vem ocorrendo nas diversas cidades ao redor do mundo, sobretudo, após o planeta ter se urbanizado e a urbanização ter se globalizado. Em Belém, capital do Estado do Pará, considerada a metrópole da Amazônia, geograficamente estratégica e com relevante importância histórica para a urbanização brasileira, não tem sido diferente, tendo em vista as recentes transformações urbanas pautadas no referido modelo de urbanização que segrega o direito à cidade.

Neste sentido, em 2017, a Prefeitura Municipal de Belém, lançou processo licitatório através do Edital de Pregão n. 084/2017 com o objetivo de "reformar" o quiosque denominado Bar do Parque para torná-lo uma "área nobre" e "bem frequentada".

Convém ressaltar que o Bar do Parque é um quiosque tombado pelo Instituto do Patrimônio Histórico e Artístico Nacional - IPHAN e pela SECULT - Secretaria de Cultura do Estado do Pará, tendo em vista a sua importância histórica e cultural para a cidade de Belém. Localizado na Praça da República, construído na década de 1930, faz parte do complexo cultural do Teatro da Paz, na área central da capital paraense. De estilo Art Nouveau, símbolo da belle époque e dos tempos áureos da extração da borracha na Amazônia, além da arquitetura peculiar, o Bar do Parque representa um dos maiores redutos da boemia paraense, espaço de deliberação política e de manifestações sociais e culturais, de protestos por liberdade e democracia, confundindo-se com a própria memória e a história da metrópole da Amazônia.

O objetivo da Prefeitura, juntamente com a empresa Barbearia Rockfeller Ltda vencedora do processo de licitação é "reformar" este espaço através da gentrificação. Tal instrumento, na prática, tem como intuito (re)construir espaços neoliberais na cidade, propiciando oportunidades para um novo desenvolvimento mais rentável, onde as necessidades das elites são satisfeitas e atendidas em detrimento da maioria dos habitantes da cidade. Trata-se de uma verdadeira "gourmetização" do espaço urbano que viola as normas urbanísticas e garante a fruição do direito à cidade apenas para alguns habitantes.

Diante disto, o problema de pesquisa a ser respondido neste artigo é: o processo de gentrificação do Bar do Parque viola a tutela urbanística do patrimônio histórico e cultural na cidade de Belém? 
Para responder ao problema acima, alguns objetivos deverão ser traçados neste artigo, como: (i) conceituar o que vem a ser o novo modelo de urbanização neoliberal; (ii) analisar o processo de gentrificação como instrumento do modelo de urbanização neoliberal; (iii) investigar se a gentrificação no Bar do Parque viola as normas urbanísticas de proteção do patrimônio histórico e cultural na cidade.

Por fim, o método científico utilizado no presente trabalho é dedutivo, pois parte-se de uma ideia universal, qual seja, a mercantilização do espaço urbano, para se compreender o que vem ocorrendo no caso concreto estudado. A pesquisa bibliográfica e documental relacionada aos estudos urbanos é de suma importância para fundamentar as teorias discutidas neste artigo, bem como, a compreensão da tutela jurídica urbanística, com influência das referências da arquitetura e do urbanismo, além dos ensinamentos da sociologia urbana. No mais, analisar o projeto urbanístico do Bar do Parque, além do processo de licitação é fundamental para compreender se, no caso concreto em questão, há violação das normas que tutelam o patrimônio histórico e cultural e o direito à cidade, esculpidas no ordenamento jurídico brasileiro.

\section{O URBANISMO NEOLIBERAL}

A cidade neoliberal é entendida como uma cidade ampla, produzida sob uma governança urbana dominante - de acordo com o modelo capitalista - cujos objetivos incluem privatização, planos globalizados, criação de fluxo, melhoria da atratividade das cidades e marketing urbano. A abordagem da cidade neoliberal leva em consideração a cidade empreendedora (LEITNER, 1990) com uma estrutura e base de ambiente urbano avassalador já que o mundo está cada vez mais se urbanizando e o espaço urbano cada vez mais se neoliberalizando (PECK; TICKELL 2002).

Esta cidade reconceitua as bases econômicas do comportamento humano e das práticas sociais (LEITNER et al. 2007), sendo um processo de reprodução capitalista flexível, que estimula a privatização, a competição e a mercantilização do urbano, a fim de impor as forças do mercado às cidades, seus lugares e seus habitantes. Dessa forma, a produção do espaço neoliberal naturalmente leva à fragmentação social e urbana, à polarização e à criação de espaços e populações marginalizados dentro da cidade (LEVY; RODRIGUES, 2017).

O mercado imobiliário representa uma das expressões mais fortes do urbanismo neoliberal, tendo em vista que sob a lógica da cidade empreendedora, desumaniza o espaço 
urbano, viola as normas urbanísticas e desconsidera a histórica e a memória da cidade. A cidade neoliberal não está subordinada às normas jurídicas, mas sim, às normas do mercado. A cidade como mercadoria (HARVEY, 1990; VÉRAS, 2000; VAINER, 2000) expressa os interesses globais do capital imobiliário que cada vez mais comercializa o espaço reproduzindo a segregação e a fragmentação como características inerentes a esta realidade.

Atualmente, sobretudo, com a influência do modelo urbano neoliberal respaldado na tecnologia e no mercado imobiliário, as transformações urbanas reestruturam de forma significativa o meio ambiente urbano ou construído, como no caso do projeto de "reforma" do Bar do Parque, a ser analisado posteriormente neste artigo.

A tendência urbano-neoliberal é maior nos países em desenvolvimento como o Brasil, onde os impactos do processo de globalização são mais avassaladores. Logo, não é de se estranhar que a consequente transformação urbana trás, em seu bojo, profundas desigualdades sociais - contradições não só herdadas da metrópole moderna, mas intensificadas por um modelo de urbanização excludente e segregador, com influencia do neoliberalismo.

O fenômeno da globalização financeira, ou mesmo da "mundialização do capital" nas palavras de Chesnais (1999), interfere no meio ambiente urbano, exigindo competitividade, competência, disputa entre cidades, cidades voltadas para disputar investimentos nos mercados internacionalizados. Destaca-se o desemprego, a exclusão, a pobreza, a diminuição de recursos para políticas sociais, a redução de espaços públicos, o aumento da desigualdade, da violência e da degradação urbana.

Há um processo simultâneo de urbanização do globo e de globalização do urbano, tendo em vista que os espaços urbanos globalizaram-se, tudo é urbano de certa maneira, posto que hoje já não se consegue definir o que é urbano. Assim, ao mesmo tempo em que o mundo está cada vez mais urbano, o urbano está cada vez mais neoliberal.

Por neoliberalismo ${ }^{1}$ entende-se o processo de transformação socioespacial, materializado por um desenvolvimento espacial desigual, por uma topografia desigualmente desenvolvida e instável que generaliza a insegurança social no espaço urbano.

Assim, o cenário do urbanismo neoliberal é extremamente incerto, caracterizado pela instabilidade monetária, por movimentos especulativos do capital financeiro, por estratégias

\footnotetext{
${ }^{1}$ Para Theodore, Peck e Brenner (2009) o neoliberalismo representa um fenômeno multiescalar, pois reconstitui relações em distintas escalas (regional, nacional e internacional) entre atores institucionais e econômicos como os Estados locais e o capital financeiro. A cidade neoliberal desenvolve centros estratégicos para o avanço desigual de projetos de reestruturação neoliberal. Para Harvey (1997) o sistema neoliberal aprofunda as relações sociais capitalistas produzindo consequências à integridade cultural e social.
} 
globais de localização de grandes companhias transnacionais, gerando uma competição cada vez maior entre localidades, característica da desordem global-local (THEODORE; PECK; BRENNER, 2009).

Nesse sentido, observa-se espaços de políticas neoliberais nas cidades como a criação de zonas empresariais, ou gathering places (OLDENBURG, 2000), baseados na parceria público-privado, impulsionados por diversas forças, dentre elas o capital imobiliário. $\mathrm{O}$ projeto do novo Bar do Parque, em Belém, é um caso exemplar da paisagem institucional do urbanismo neoliberal, agitado e dinâmico, fruto da criatividade contraditória deste processo.

Este novo modelo de urbanização se materializa nas recentes tendências de apropriação da cidade por interesses empresarias globais, redefinindo os diferentes espaços, descaracterizando a memória, a histórica e a cultura urbana, violando as normas urbanísticas e segregando os espaços e seus usos através de um instrumento denominado gentrificação.

\section{O PROCESSO DE GENTRIFICAÇÃO COMO INSTRUMENTO DO URBANISMO NEOLIBERAL E A VIOLAÇÃO DO ORDENAMENTO JURÍDICO URBANÍSTICO.}

Gentrification ou gentrificação é um processo que ocorre em áreas urbanas cuja desvalorização e falta de infraestrutura propiciam oportunidades para um novo desenvolvimento mais rentável, onde as necessidades das elites são satisfeitas e atendidas em detrimento de uma grande parcela da população afetada pela instabilidade do trabalho, desemprego e estigmatização (SLATER, 2011).

Essa "política" urbana de revalorização, que ocorre sobretudo nas áreas centrais das cidades - com o objetivo de torná-las mais atrativas economicamente - se por um lado tenta "reurbanizar" a cidade, por outro, acarreta na perda da memória, da cultura e da história do espaço urbano, sobretudo, quando ocorre em bens ou monumentos culturais e históricos tombados, como no caso do Bar do Parque. Além disso, viola normas urbanísticas, já que, em geral “o Estado não intervém através das políticas de gentrification para assegurar a equidade dos usos do espaço, mas para realçar privilégios” (LEITE, 2006, p. 42).

É certo que a modificação do espaço urbano pela gentrificação ${ }^{2}$ pode contribuir com a melhoria da qualidade de vida na cidade, entretanto, vem sendo utilizado para garantir a valorização do território e da especulação imobiliária - tão condenada pelo Estatuto da

${ }^{2}$ Sobre o conceito e os efeitos do processo de gentrification ver: Ley (1994) e Shaw (2008).

Revista de Direito Urbanístico, Cidade e Alteridade | e-ISSN: 2525-989X | Salvador | v. 4 | n. 1 | p. 39 - 58 | Jan/Jun. 2018 
Cidade - sob a égide da elitização e do enobrecimento, tratando-se de uma intervenção de caráter eminentemente político, cujos efeitos não são outros, senão a intensificação da segregação e da fragmentação em metrópoles, sobretudo, tão desiguais como Belém.

Neste sentido, tal processo específico de recentralização socialmente seletiva nas áreas centrais da cidade, tem contribuído para a fragmentação social e residencial do espaço urbano contemporâneo. Para Mendes (2011, p. 479) “a gentrificação passou a constituir-se como estratégia global ao serviço do urbanismo neoliberal e dos interesses da reprodução capitalista e social, tendo-se generalizado por todo o mundo urbano".

É neste sentido que se entende a gentrificação como instrumento do urbanismo neoliberal, tendo em vista que com a globalização do urbano, revela-se a constituição de processos de promoção e marketing imobiliário submetidos à mediação do mercado e que, mais do que nunca, contribuem para transformar o espaço urbano em mercadoria.

As novas políticas urbanas traduzem maior orientação para o mercado e para os consumidores, em detrimento das classes mais desfavorecidas, isto porque:

\begin{abstract}
(...) o desenvolvimento de parcerias público-privado que nesse quadro é frequente se desenhar, constitui um verdadeiro subsídio aos mais ricos, ao tecido empresarial mais poderoso e às funções e relações estratégicas de controle, poder e dominação do espaço urbano, condição fundamental na perpetuação da reprodução do capital, premissa essencial para o suporte do sistema de produção e consumo capitalista. Tudo isso à custa dos investimentos em serviços locais de consumo coletivo. É que se, em última análise, a atração e o crescimento propiciados pela gentrificação a todos beneficiam, em primeiro lugar ganham os promotores imobiliários, as empresas e as instituições financeiras, muito frequentemente à custa da expulsão dos residentes e das empresas mais débeis dos lugares requalificados, lançados por via dessa (des)valorização, num processo de exclusão (MENDES, 2011, p. 481).
\end{abstract}

Assim, percebe-se a clara relação entre gentrificação e urbanismo neoliberal, tendo em vista que um dos objetivos deste processo é mercantilizar a cidade, transformar o espaço urbano em produto para se obter lucro.

Esta lógica é totalmente contrária às normas urbanísticas dispostas no Ordenamento Jurídico Brasileiro, e viola a tutela de proteção ao meio ambiente urbano e cultural $^{3}$,

\footnotetext{
${ }^{3}$ Entende-se por Meio Ambiente Artificial ou Urbano aquela espécie de meio ambiente "constituído pelo espaço urbano construído, consubstanciado de edificações (espaço urbano fechado) e dos equipamentos públicos (ruas, praças, áreas verdes, espaços livres em geral: espaço urbano aberto)" (SILVA, 2013, p. 21). Por outro lado, entende-se por Meio Ambiente Cultural como aquela espécie de meio ambiente "integrado pelo patrimônio histórico, artístico, arqueológico, paisagístico, turístico, que, embora artificial, em regra, como obra do homem, difere do anterior - meio ambiente artificial - (que também é cultural) pelo sentido de valor especial que adquiriu ou de que se impregnou" (SILVA, 2013, p. 21). Para mais informações ver Milaré (2015).
} 
consagrada na Constituição Federal de 1988 e no Estatuto da Cidade, Lei n. 10.257/2001, senão vejamos:

$\mathrm{O}$ art. 182 da Carta Magna dispõe sobre a Política de Desenvolvimento Urbano ${ }^{4}$, a qual deverá ser executada pelo Poder Público Municipal, conforme as diretrizes gerais fixadas em lei e "tem como objetivo ordenar o pleno desenvolvimento das funções sociais da cidade e garantir o bem- estar de seus habitantes" (BRASIL, 1988).

O princípio basilar de todo o Ordenamento Urbanístico é aquele que pauta a Política Nacional de Desenvolvimento Urbano, qual seja o Princípio da Função Social da Cidade. Tal regramento, também fundamentado no art. $5^{\circ}$, XXIII da $\mathrm{CF} / 88$, visa garantir a todos os direitos inerentes à cidade além do pleno desenvolvimento e bem estar de seus habitantes através da instrumentalização e adequada ordenação da cidade, possibilitando a intervenção direta do Estado na propriedade privada em prol da coletividade.

Edésio Fernandes (2006) entende que, entre as quatro dimensões fundamentais do Estatuto da Cidade, a primeira a ser consolidada foi a noção da função social e ambiental da propriedade e da cidade como o marco conceitual jurídico-político para o direito urbanístico.

O Estatuto da Cidade, Lei n. 10.257/2001, que regulamenta toda a Política Urbana no Brasil, estabelece diretrizes gerais, instrumentos urbanos como o plano diretor, além de prever a gestão democrática da cidade. Na mesma linha, normatiza o princípio da Função Social da Cidade, sendo aquele que proporciona a seus habitantes uma vida com qualidade, satisfazendo os direitos fundamentais individuais e coletivos previstos na Carta Magna.

Uma das diretrizes disposta no art. $2^{\circ}$, XII do Estatuto é a proteção, preservação e recuperação do meio ambiente natural e construído, do patrimônio cultural, histórico, artístico, paisagístico e arqueológico.

Portanto, toda e qualquer iniciativa que viole tais normas urbanísticas - como o caso do Bar do Parque em Belém - que desconsidere o princípio da função social da cidade e, principalmente, que desconfigure o patrimônio cultural e histórico da cidade, segregando e fragmentando a espaço urbano, deve ser vetada ou rechaçada para que não se aprofunde ainda mais a desigualdade nas cidades.

\footnotetext{
${ }^{4}$ O Ministério das Cidades defende que a Política Nacional de Desenvolvimento Urbano é um conjunto de princípios, diretrizes e objetivos, construídos democraticamente, a partir da $1^{\text {a }}$ Conferência Nacional das Cidades em 2003, para nortear os investimentos em habitação, saneamento ambiental, mobilidade urbana, transporte e trânsito, bem como promover uma política fundiária e imobiliária includente e fortalecer institucionalmente os municípios brasileiros (MINISTÉRIO DAS CIDADES, 2004).
} 
Isto porque, o conceito de cidade que o Estatuto regulamenta é o de cidade sustentável $^{5}$ (disposto no art. $2^{\circ}$, I da Lei n. 10,257/01), cidade compartilhada, aquela cidade que todos possam livremente e democraticamente usufruir do direito à cidade ${ }^{6}$, cuja prioridade é a construção de uma cidade inclusiva e não exclusiva, através de um espaço urbano que integre e não que segregue. Desta forma, é possível que a política urbana atenda ao seu principal objetivo, qual seja: ordenar o pleno desenvolvimento das funções sociais da cidade e da propriedade urbana.

\section{O BAR do PARQUe COMO PATRIMÔNiO CUltural da CIDAde DE BELÉM}

\subsection{Breve relato sobre o Bar do Parque:}

O quiosque denominado Bar do Parque é proveniente da Belle Époque ${ }^{7}$, período conhecido como a Idade do Ouro do estilo de vida burguês e urbano, proveniente da Paris Fin de Siècle, em que Belém sofreu forte influência, entre o final do século XIX e início do século XX. Neste momento, a cidade passa por um intenso processo de urbanização e

\footnotetext{
${ }^{5}$ O conceito legal de Cidades Sustentáveis está disposto no art. 2, I do Estatuto da Cidade, "entendido como o direito à terra urbana, à moradia, ao saneamento ambiental, à infra-estrutura urbana, ao transporte e aos serviços públicos, ao trabalho e ao lazer, para as presentes e futuras gerações" (BRASIL, 2001). Para Gomes e Zambam (2018, p. 327-328), a cidade sustentável está atrelada a um "conceito delineado por um viés teórico, representando o espaço artificial pautado pelo equilíbrio entre o crescimento econômico, desenvolvimento social e proteção ambiental" (...) Cidades sustentáveis e/ou inteligentes são aquelas que se desenvolvem de maneira planejada (mensuráveis por intermédio de indicadores básicos como economia, qualidade de vida, mobilidade) e que, segundo dados do ranking 'Connected Smart Cities' na pesquisa 'Urban Systems', cuja avaliação é pautada em critérios de inteligência, conexão e sustentabilidade econômica e ambiental, estão atreladas também a inovação na aplicação dos instrumentos legais já existentes".

${ }^{6}$ Para Osório (2006, p. 195): o Direito à Cidade é aquele "[...] interdependente a todos os direitos humanos internacionalmente reconhecidos, concebidos integralmente, e inclui os direitos civis, políticos e econômicos, sociais, culturais e ambientais. Inclui também o direito a liberdade de reunião e organização; o direito ao exercício da cidadania, e da participação no planejamento, produção e gestão da cidade; a produção social do habitat; o respeito às minorias e a pluralidade étnica, racial, sexual e cultural; o respeito aos imigrantes e a garantia da preservação e herança histórica e cultural. O Direito à Cidade inclui também o direito ao desenvolvimento, a um meio ambiente sadio, ao desfrute e preservação dos recursos naturais e à participação no planejamento e gestão urbanos".

${ }^{7}$ O período da Belle Époque em Belém, entre o final do século XIX e início do século XX, é fundamental para se compreender o processo de urbanização da capital paraense, tendo em vista, que nesta epóca, influenciado pelo estilo de vida burguês parisiense, o então intendente Antonio Lemos criou uma política de reordenamento urbano, saneamento e embelezamento da cidade, com base no modelo de urbanismo vigente na Europa, em especial na França. Era o brilho da Belle Époque que pretendia transformar Belém em uma pequena reprodução da cidade europeia (SARGES, 2000).
}

Revista de Direito Urbanístico, Cidade e Alteridade | e-ISSN: 2525-989X | Salvador | v. 4 | n. 1 | p. 39 - 58 | Jan/Jun. 2018 
embelezamento, com a construção de praças, coretos, quiosques e grandes avenidas, seguindo o modelo europeu que influenciava o tempo áureo da borracha.

Em 1878, Antonio Lemos, então intendente de Belém, fez modificações na estrutura da chamada Praça da República, considerada cartão postal da capital paraense, um dos principais pontos turísticos da cidade, que abriga além de um bonito encantador paisagismo com árvores frondosas e belíssimos monumentos, construções importantes para a cidade como o Teatro Waldemar Henrique e o exuberante Teatro da Paz. Ao lado do Teatro da Paz, próximo à Rua da Paz, na Praça da República, foi construído para ser a bilheteria do teatro, um quiosque em alvenaria em estilo Art Nouveau, lembrando os cafés parisienses, onde, durante muitas décadas, funciona o "Bar do Parque".

Esta edificação, bem como o Teatro da Paz, a Praça da República e o seu entorno, fazem parte do conjunto arquitetônico paisagístico e urbanístico dos bairros da Cidade Velha e Campina, na cidade de Belém, tombados na instância federal pelo IPHAN - Instituto do Patrimônio Histórico e Artístico Nacional ${ }^{8}$, cuja função é proteger e manter os monumentos históricos da cidade, e guardar para as gerações futuras a oportunidade de conhecer e vivenciar o patrimônio cultural brasileiro que faz parte da história de construção da nação e das identidades locais.

Além disso, em 1983, a Praça da República e todas as edificações que nela existem, como o Bar do Parque, também foram tombadas na esfera estadual pelo Departamento de Patrimônio Histórico, Artístico e Cultural - DPHAC, da Secretaria de Cultura do Estado do Pará - SECULT ${ }^{9}$.

\footnotetext{
${ }^{8}$ O Bar do Parque está dentro da área de tombamento referente ao Processo do IPHAN n. 1.071-T-82 que compreende o Conjunto Arquitetônico, Urbanístico e Paisagístico dos bairros da Cidade Velha e Campina. Disponível em: http://portal.iphan.gov.br/uploads/atas/2011_01_67a_reunio_ordinria_3_de_maio.pdf. Acesso em 06 abr. 2018.

9 Para verificar a relação de bens tombados pelo Governo do Estado do Pará, ver: http://www.aedmoodle.ufpa.br/pluginfile.php?file=/175047/mod_page/content $/ 12 /$ Listagem\%20bens\%20Tomba dos\%20Capital\%20-\%202012.pdf.
}

Revista de Direito Urbanístico, Cidade e Alteridade | e-ISSN: 2525-989X | Salvador | v. 4 | n. 1 | p. 39 - 58 | 


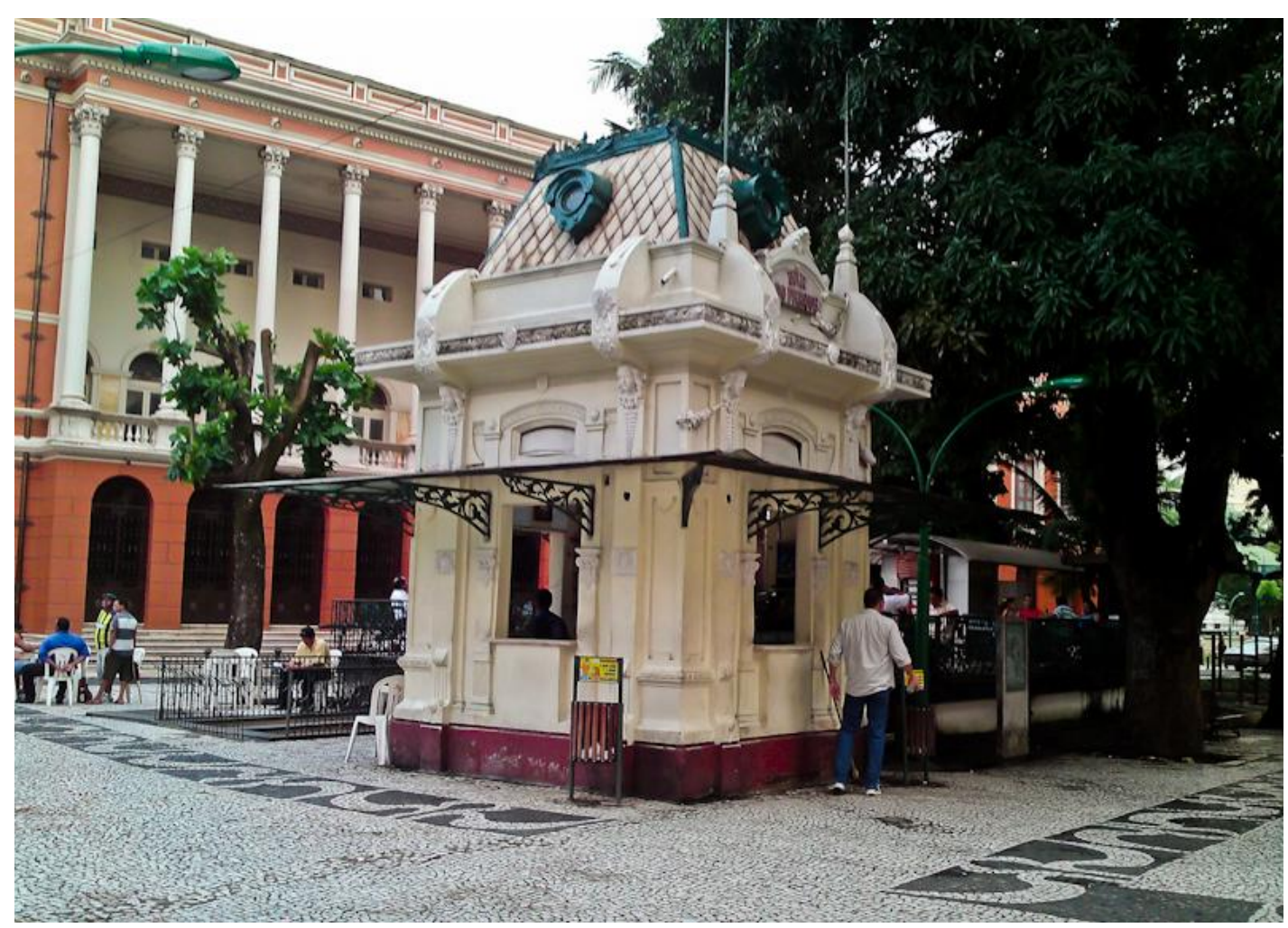

Figura 1. Bar do Parque. Foto de Luis Cláudio.

Em 2005, mediante levantamento realizado pela FUMBEL - Fundação Cultural de Belém, constante às fls. 75 do Edital de Pregão Presencial n. 084/2017, o Departamento de Patrimônio Histórico - DEPH constatou que o Bar do Parque estava em péssimo estado de conservação, deteriorado, desgastado, com algumas estruturas quebradas e corroídas, e de forma geral o bar encontrava-se muito sujo, com lixo e entulho.

Além disso, a Secretaria Municipal de Economia da Prefeitura Municipal de Belém detectou que o bem não estava sendo utilizada de forma regular, haja vista a inexistência de informações da permissão de uso do espaço "Bar do Parque".

Neste mesmo levantamento, a FUMBEL apresentou uma relação de serviços necessários a serem feitos para a manutenção do Bar do Parque, tendo em visto o uso do espaço de forma irregular.

Ocorre que, há mais de cinquenta anos, o Bar do Parque vem sendo administrado por uma família a qual tinha a concessão de uso do bem público, porém, há dois anos a Prefeitura de Belém isolou a área, destituindo a família e os funcionários do local, com o pretexto de reformar a Praça da República e o espaço que estava degradado.

A justificativa da Prefeitura foi de que "o modelo de gestão que estava sendo feito no Bar do Parque não contribuía para a revitalização da área e o novo modelo, muito comum na 
Europa, traz uma vitalidade maior para o local resgatando a originalidade do próprio Bar do Parque, tradicionalmente muito bem frequentado, resgatando um ambiente voltado para a coletividade" (DOL, 2017).

Vale ressaltar que em nenhum momento a Prefeitura de Belém rescindiu formalmente o contrato de uso de Bem Público com a família que há décadas administrava o Bar do Parque, tampouco comunicou aos administradores que faria uma licitação para conceder o uso para uma nova empresa, muito menos, utilizou-se de qualquer instrumento, como as audiências públicas, por exemplo, para publicizar a situação do Bar do Parque e proporcionar a participação da sociedade em deliberar sobre o futuro deste patrimônio histórico e cultural tão importante para a cidade.

\subsection{O Bar do Parque como Patrimônio Cultural da Cidade de Belém.}

Primeiramente, convém demonstrar o conceito e a importância do tombamento existente na legislação brasileira, para então se compreender o Bar do Parque como patrimônio histórico e cultural da cidade de Belém.

Segundo Di Pietro (2005, p. 134):

\footnotetext{
O tombamento pode ser definido como o procedimento administrativo pelo qual o poder público sujeita a restrições parciais os bens de qualquer natureza cuja conservação seja de interesse público, por sua vinculação a fatos memoráveis da história ou por seu valor arqueológico ou etnológico, bibliográfico ou artístico.
}

Em sendo um ato discricionário da Administração Pública, que pode ocorrer nas esferas nacional, estadual e municipal, o tombamento atinge bens móveis e imóveis, materiais e imateriais, públicos e privados, quando a conservação dos mesmos é de interesse público, quer por sua vinculação a fatos memoráveis da história do Brasil, quer por seu excepcional valor arqueológico ou etnográfico, bibliográfico ou artístico, nos termos do art. $1^{\circ}$ do DecretoLei n. 25/1937.

Qualquer pessoa física ou jurídica pode pedir o tombamento de um bem com valor cultural. Após a avaliação técnica preliminar do órgão competente, o processo é encaminhado ao Departamento ou Conselho consultivo correspondente para definir pelo tombamento ou não do bem. Vale lembrar que o tombamento não altera a propriedade do bem, apenas impede que seja destruído ou descaracterizado. Por fim, um imóvel, por exemplo, pode ser alugado para outros fins diferentes do qual foi construído, desde que o outro uso não descaracterize a 
edificação, uma vez que o objetivo é "manter os valores históricos e culturais preservados, adaptando o antigo à vida moderna sem descaracterizar as ruas, edificações e a paisagem". (IPHAN, 2015).

A primeira norma significativa a disciplinar a proteção do patrimônio histórico e artístico nacional, e determinar o processo a ser seguido para tombar bens, os efeitos e sanções administrativas para as infrações cometidas contra os bens tombados, foi o DecretoLei n. ${ }^{\circ} 25 / 37$.

Porém, somente com a Constituição Federal de 1988 que a tutela desses bens alçou ao patamar constitucional, com base no art. 215 que determina a proteção dos direitos culturais, sendo que o Estado deve garantir "a todos o pleno exercício dos direitos culturais e acesso às fontes da cultura nacional, e apoiará e incentivará a valorização e a difusão das manifestações culturais" (BRASIL, 1988).

No mesmo sentido, define no art. 216 que as formas de expressão, as criações artísticas, as obras e demais espaços destinados às manifestações artístico-culturais como bens de natureza material e imaterial que constituem o patrimônio cultural brasileiro, devem ser protegidos e preservados pelo Poder Público, pois referem-se à identidade, à ação, à memória dos diferentes grupos formadores da sociedade brasileira (BRASIL, 1988).

Um importante instrumento internacional que regulamenta a matéria é a Convenção para a Proteção do Patrimônio Mundial, Cultural e Natural da UNESCO $^{10}$ de 1972, a qual define como espécie de patrimônio cultural:

\footnotetext{
Artigo 1: Definições do patrimônio cultural e natural:

Para fins da presente Convenção serão considerados como patrimônio cultural:

Os monumentos. - Obras arquitetônicas, de escultura ou de pintura monumentais, elementos de estruturas de carácter arqueológico, inscrições, grutas e grupos de elementos com valor universal excepcional do ponto de vista da história, da arte ou da ciência (UNESCO, 1972).
}

Assim, pode-se perceber que o conceito de patrimônio cultural é abrangente, e determina o "conjunto dos bens materiais e imateriais representativos para dada comunidade e cuja tutela se orienta pelo disposto na Constituição da República” (PAIVA, 2015, p. 679).

Por outro lado, o conceito de bem cultural é o "significado contido em uma expressão cultural, material ou imaterial, podendo ser ainda uma memória cultural, legitimamente considerada e consolidada como um valor cultural representativo e expressivo para uma

${ }^{10}$ Disponível em: https://whc.unesco.org/archive/convention-pt.pdf. Acesso em: 06 abr. 2018. 
comunidade local, regional ou global, e cuja tutela se orienta pela Constituição da República de 1988" (PAIVA, 2015, p. 95).

Para Milaré (2015, p. 319) o patrimônio ambiental cultural é composto por todos os bens "que sejam portadores de referência à identidade, à ação, à memória dos diferentes grupos formadores da nacionalidade ou sociedade brasileiras, [...]", e elucida, "Destarte, não se discute mais [ ...]; se dele faz parte tão só a arte erudita ou de igual modo a popular”.

Toda esta discussão é válida, tendo em vista que o momento atual, pautado pela globalização e transformação social, acarreta fortes intervenções, sobretudo, em bens culturais (materiais e imateriais) que compõe o espaço urbano. Os processos de gentrificação nas áreas degradas e centrais das cidades é um exemplo genuíno dessas transformações.

Tal processo fica mais latente se relacionarmos à proteção do patrimônio cultural no espaço urbano, tendo em vista que quase nunca se respeita a memória e história da cidade, do meio ambiente construído, enaltecendo a cidade de consumo, pautada numa (so)ci(e)dade do espetáculo $^{11}$, cenográfica. Este cenário resume a proteção colonialista, hegemônica e global do patrimônio, em que o material é mais relevante (lucrativamente) do que o imaterial, ou mesmo, o moderno é mais importante que antigo, e o novo é mais atraente que o velho.

\subsection{Análise do Processo Licitatório n. 084/2017 e do Projeto Arquitetônico do Bar do}

\section{Parque}

Imbuída pela tendência de um modelo urbano neoliberal, cuja a gentrificação é um instrumento básico para a promoção de transformações urbanas, no ano de 2017, a Prefeitura de Belém, por intermédio da Secretaria Municipal de Economia - SECON, lançou processo licitatório n. 084/2017 na modalidade de Pregão Presencial ${ }^{12}$ para "Permissão de Uso de Bem Público, de forma onerosa, para exploração comercial de serviços de alimentação na modalidade Lanchonete e Café no espaço denominado Quiosque "Bar do Parque" localizado no Complexo da Praça da República, do tipo maior oferta (PREFEITURA MUNICIPAL DE BELÉM, 2017).

\footnotetext{
${ }^{11}$ Debord assinala que vivemos hoje numa sociedade do espetáculo em que a vida não passa de uma grande representação e a aparência, ou seja, o parecer (em contraposição ao ser e ao ter) constitui o modelo atual da vida dominante em sociedade. A cidade do espetáculo é o palco e o cenário deste novo estilo de vida.

${ }^{12}$ Para Gasparini (2006, p. 38) "Pregão é o procedimento administrativo mediante o qual a pessoa obrigada a licitar, seleciona para a aquisição de bens comuns ou para a contratação de serviços comuns, dentre as propostas escritas, quando admitidas, melhoráveis por lances verbais ou virtuais, apresentadas pelos pregoantes em sessão pública presencial ou virtual, em fase de julgamento que ocorre antes da habilitação".
} 
Vale ressaltar que - sem nenhum aviso prévio, debate público com a sociedade ou com a família que administrava o bar - a classificação das propostas seria com base na maior oferta, isto é, na empresa licitante que apresentasse o maior valor para a concessão de outorga de uso de bem público com o objetivo de implementar exploração comercial de serviços de alimentação.

Ora, três observações iniciais quanto ao Edital devem ser feitas até aqui: (i) o Edital é claro com o objetivo proposto: permissão de uso de Bem Público de forma onerosa, para exploração comercial de serviços de alimentação; (ii) em nenhum momento permite requalificação, "reforma", "revitalização" ou qualquer outra transformação do quiosque Bar do Parque; (iii) o próprio Edital reconhece a necessidade se enobrecer o Bar do Parque para torná-lo um local "melhor frequentado".

O Edital prevê ainda a rescisão do contrato de permissão inclusive com arbitramento de multa a ser paga pela empresa permissionária, sobretudo, se violar as normas legais vigentes e o referido Edital.

A empresa vencedora do processo de licitação foi a Barbearia Rockfeller Ltda, a qual tem como principal atividade uma barbearia localizada no centro da capital paraense. O lance inicial do Edital para concessão de uso do bem era o valor mensal de R $\$ 4.856,11$ (quatro mil, oitocentos e cinquenta e seis reais e onze centavos); a empresa ganhadora, ofertou R\$ $8.300,00$ (oito mil e trezentos reais).

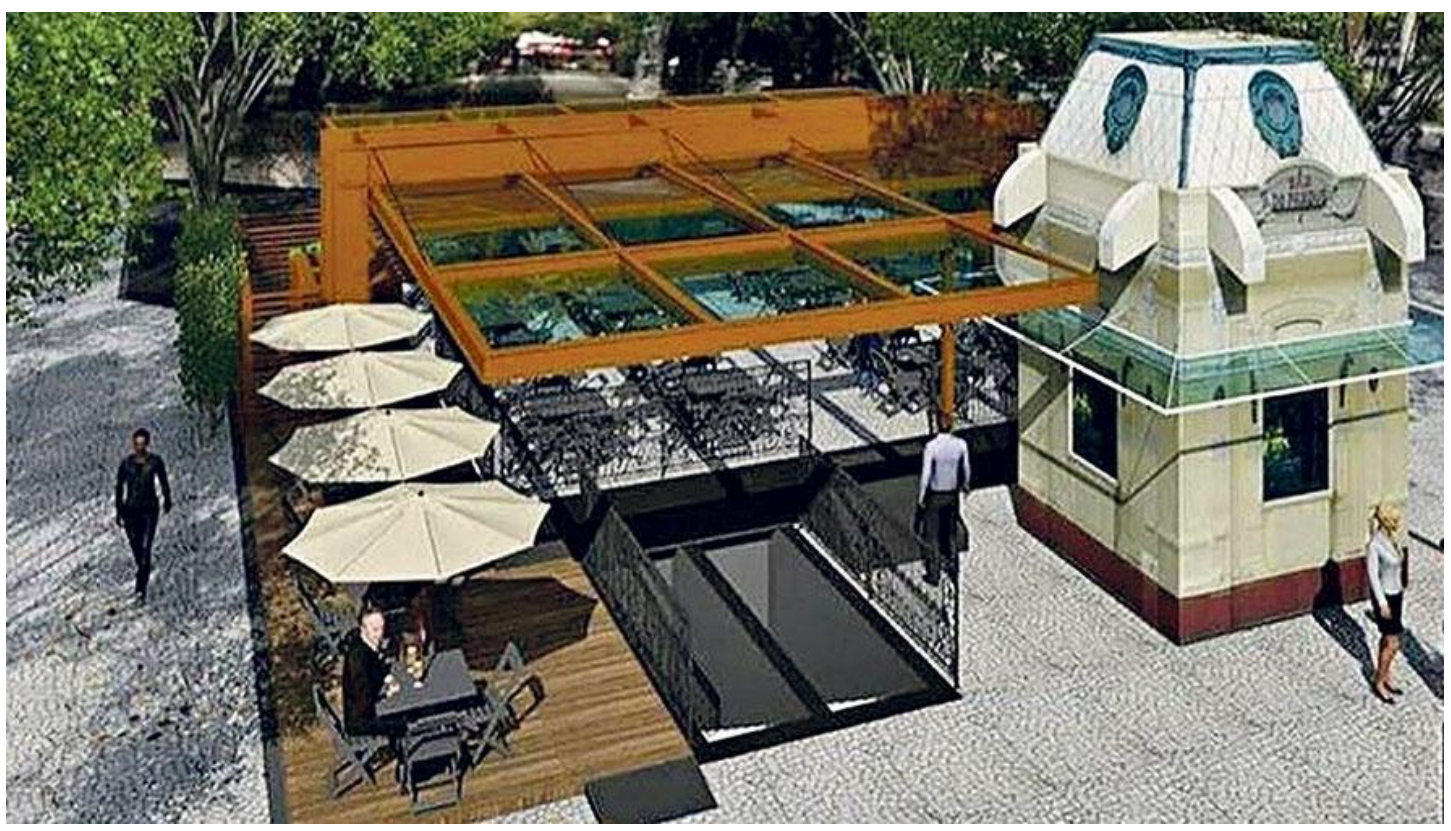

Figure 2. Projeto Arquitetônico para remodelação do Bar do Parque (DOL, 2018). 
A empresa foi habilitada e apresentou projeto arquitetônico para reforma e requalificação do Bar do Parque, e após divulgação nas mídias sociais, sofreu forte pressão e crítica da sociedade.

Segundo o Sindicato de Hotéis e Bares do Pará, a licitação foi uma surpresa para os atuais gestores do espaço, tendo em vista que estes concessionados não foram informados da licitação em curso. O Sindicato ameaçou ingressar com um Mandado de Segurança para tentar suspender a licitação, pois entende que apesar da Prefeitura ter o direito de realizar a licitação de um espaço público, o processo ocorre de forma equivocada (DOL, 2017).

Ainda quanto ao processo licitatório e ao projeto arquitetônico:

A descaracterização do uso do Bar do Parque escamoteia as velhas narrativas de poder que se utilizam dos interesses econômicos para se apropriar do patrimônio cultural, conceito que só se sustenta a partir da valoração das comunidades e grupos populares, mas como está sendo apropriado mais uma vez para conveniência dos órgãos de poder é improvável que a Prefeitura de Belém esteja olhando para isso (VIEIRA; SOBRAL, 2017).

Como se viu, o bem tombado não pode ser demolido, destruído, mutilado ou descaracterizado, podendo ser reparado, pintado, restaurado, ou por qualquer forma alterado, com prévia autorização.

Porém, o que se percebe no presente projeto é que, com o aval da Prefeitura Municipal de Belém, e sob a justificativa da parceria público-privado, a real intenção da empresa licitante não é outra senão, descaracterizar ou desconfigurar um patrimônio cultural tombado, reformar e enobrecer o Bar do Parque para torná-lo bem frequentado, "gourmetizar" e elitizar o quiosque, violando inclusive as normas urbanísticas.

O referido Edital é orientado tanto para a seleção de um administrador oriundo do empresariado mais tradicional como para a formação de outro tipo de público no local, este que pode pagar preços mais altos do padrão da "gourmetização" dos espaços.

Claro está que o processo de licitação para a nova administração do Bar do Parque, com requisitos que o descaracterizam completamente, se destaca como mais uma medida de mercantilização da cidade, segregação e higienização dos espaços públicos.

Vale ressaltar que no último dia 28 de março de 2018, o Secretário de Cultura do Estado do Pará suspendeu a execução do projeto arquitetônico, mesmo após a empresa licitante Rockfeller Ltda ter tido êxito no Pregão Presencial, sob a justificativa de que o projeto apresentado não se coaduna com o "conjunto arquitetônico do local” e que “não comtempla a memória artística, poética e estética da cidade” (DOL, 2018). 
Desta sucinta análise, percebe-se que o projeto do Bar do Parque sintetiza o que Leite (2006, p. 28) afirma sobre os projetos de requalificação urbana: "por realçarem os aspectos mercadológicos do patrimônio, alteram também o sentido público e político do espaço urbano, ao tomar o cidadão como consumidor, atualizando os nexos entre cultura de consumo e produção de mercadorias".

Enquanto muitas cidades ao redor do mundo, como Paris, estão desenvolvendo planos radicais de combate à gentrificação ${ }^{13}$, a Prefeitura de Belém utiliza este instrumento como forma de obter lucro, tendo em vista que a verdadeira intenção com este projeto não é apenas requalificar o Bar do Parque, mas implantar uma higienização do local, ou seja, "revalorizar" o patrimônio histórico e cultural como verdadeiro apelo às classes mais abastadas da cidade, para que possam frequentar este novo espaço, mais bonito, mais limpo, mais enobrecido e mais pausterizado, como antigos cafés parisienses.

\section{CONCLUSÃO}

Este artigo teve a pretensão de analisar a mercantilização do espaço urbano amazônico, trazendo à tona o caso do Bar do Parque, antigo quiosque de estilo Art Nouveau, tombado pelo IPHAN e pela SECULT-PA, historicamente importante e culturalmente relevante para a cidade, considerado verdadeiro patrimônio cultural para a metrópole da Amazônia, o qual será gentrificado através de processo licitatório conduzido pela Prefeitura, sob o fundamento da parceria público-privado.

Para responder ao problema de pesquisa - se o processo de gentrificação do Bar do Parque viola a tutela urbanística do patrimônio histórico e cultural na cidade de Belém? -, alguns objetivos foram traçados, quais sejam: (i) conceituar o que vem a ser o novo modelo de urbanização neoliberal; (ii) analisar o processo de gentrificação como instrumento do modelo de urbanização neoliberal que viola as leis urbanísticas; (iii) investigar se a gentrificação no Bar do Parque viola as normas urbanísticas de proteção do patrimônio histórico e cultural na cidade.

Como resposta ao problema de pesquisa, entende-se que sim, o processo de gentrificação implantado no Bar do Parque, viola as leis urbanísticas dispostas no ordenamento jurídico brasileiro, sobretudo, o princípio da função social da cidade, e das

13 Disponível em: https://www.archdaily.com.br/br/759927/paris-anuncia-medidas-radicais-para-impedirgentrificacao. Acesso em 06 abr. 2018

Revista de Direito Urbanístico, Cidade e Alteridade | e-ISSN: 2525-989X | Salvador | v. 4 | n. 1 | p. 39 - 58 | 
cidades sustentáveis, tendo em vista que descaracteriza a estrutura arquitetônica, e o uso de um espaço tombado, além de desconfigurar a memória e a história de um patrimônio cultural, contribuindo para a fragmentação e segregação do espaço urbano amazônico.

Isto porque, a maioria dos casos de gentrificação em países em desenvolvimento como o Brasil, caracterizam-se pelo abandono estatal das políticas de investimento urbano, além da própria ressignificação do uso desses espaços, ou seja, do "contra-uso" dos mesmos, uma vez que, após requalificados apresentam novas proposições oficiais tanto de utilização do patrimônio quanto de planejamento urbano, desconfigurando assim a sua finalidade, como no caso do Bar do Parque.

Assim, é imperativo que se garanta a tutela do patrimônio cultural na cidade, tendo em vista que contribui diretamente para a garantia da diversidade cultural e do desenvolvimento sustentável no meio ambiente construído.

Em tempos de mercantilização dos espaços no capitalismo neoliberal, ações de revitalização urbana muitas vezes invisibilizam processos de gentrificação, termo que exemplifica o fenômeno que afeta uma região ou bairro pela alteração das dinâmicas da composição do local, tal como novos pontos comerciais ou construção de novos edifícios, valorizando a região e afetando a população de baixa renda local, que é expulsa em virtude do aumento dos preços. O que fundamenta essas transformações são sempre interesses privados travestidos de interesses públicos.

Patrimônios Culturais como o Bar do Parque devem ser valorizados pela produção simbólica coletiva e não pela escolha unidirecional do poder municipal, uma vez que são tombados, devendo sim serem preservados, conservados e mantidos adequadamente, porém com um objetivo primordial, contribuir para a garantia do pleno desenvolvimento socioambiental e cultural do espaço urbano diverso, em que todos e todas possam disfrutar do direito à cidade. A cidade não é mercadoria, a cidade não é um produto, mas um espaço de convivência sociocultural onde se deve viver dignamente.

\section{BIBLIOGRAFIA}

ARCHDAILY. Paris anuncia medidas radicais para impedir a gentrificação. Disponível em: https://www.archdaily.com.br/br/759927/paris-anuncia-medidas-radicais-para-impedirgentrificacao. Acesso em 06 abr. 2018. 
BRASIL. Constituição Federal de 1988. Disponível em: Disponível em: www.planalto.gov.br/ccivil_03/constituicao/constituicao.htm. Acesso em: 27 mar. 2018.

BRASIL. Estatuto da Cidade. Lei n. 10.257 de 10 de julho de 2001. Disponível em: www.planalto.gov.br/Ccivil_03/leis/LEIS_2001/L10257.htm. Acesso em: 29 mar. 2018.

CHENAIS, François. "Um Programa de ruptura com o neoliberalismo" In: HELLER, Agnes (et al.) A Crise dos paradigmas em ciências sociais e os desafios para o século XXI. Rio de Janeiro: Contraponto, 1999.

DEBORD, Guy. A sociedade do espetáculo. Rio de Janeiro: Contraponto, 1997.

DI PIETRO, Maria Sylvia Zanella. Direito Administrativo. 18. ed. São Paulo: Atlas, 2005.

DOL - Diário Online. Prefeitura vai transformer Bar do Parque em Lanchonete. 2017.

Disponível em: http://www.diarioonline.com.br/noticias/para/noticia-455656-.html. Acesso em 06 abr. 2018.

DOL - Diário Online. Paulo Chaves barra projeto de novo Bar do Parque. 2018.

Disponível em: http://m.diarioonline.com.br/noticias/para/noticia-497129-paulo-chaves-barraprojeto-do-novo-bar-do-parque.html. Acesso em 06 abr. 2018.

FERNANDES, Edésio. 'Estatuto da Cidade: promovendo o encontro das agendas 'verde' e 'marrom'”. In: STEINBERGER, Marília (Org.). Território, ambiente e políticas públicas espaciais. Brasília: Paralelo 15, 2006.

GASPARINI, Diógenes. Pregão presencial. In: GASPARINI, Diógenes (Coord.). Pregão presencial e eletrônico. Belo Horizonte: Fórum, 2006.

GOMES, Daniela; ZAMBAM, Neuro José. "Sustentabilidade do espaço urbano: novas tecnologias e políticas públicas urbanístico-ambientais". Revista de Direito da Cidade, [S.1.], v. 10, n. 1, p. 310-334, jan. 2018. Disponível em: www.epublicacoes.uerj.br/index.php/rdc/article/view/29866/23349. Acesso em: 29 mar. 2018.

HARVEY, David. Los limites del capitalismo y la teoría marxista. México: Fondo de cultura económica, 1990.

Justice, nature and the geography of difference. Oxford, UK: Blackwell, 1997.

IPHAN - Instituto do Patrimônio Histórico e Artístico Nacional. Fiscalização - orientações para usuários de bens tombados. Disponível em:

https://casadopatrimoniopa.files.wordpress.com/2015/02/fiscalizac3a7c3a3oorientac3a7c3b5es-para-usuc3a1rios-de-bens-tombados.pdf. Acesso em 06 abr. 2018.

LEITE, Rogério Proença. "Margens do dissenso: espaço, poder e enobrecimento urbano". In: FRÚGOLI JR. H.; ANDRADE, L. T.; PEIXOTO, F.A. (orgs). As cidades e seus agentes: práticas e representações. Belo Horizonte: Puc-Minas/Edusp, 2006.

LEVY, Dan Rodrigues; RODRIGUES, Claudia Barbosa. "Urban Resilience and Resistance in the Neoliberal City: The cases of Comunidade Coliseu (Brazil-São Paulo) and ES.COL.A da Fontinha (Portugal-Porto)". In: ERDI, Gulçin; SENTURK, Yildirim. Identity. Justice and Resistance in the Neoliberal City. London: Palgrave Macmillan, 2017, p. 247-274.

LEY, David. "Gentrification and the politics of the new middle class" In: Environment and Planning D: Society and Space, 12(1), 1994, p. 53-74.

LEITNER, Helga. "Cities in pursuit of economic growth: The local state as entrepreneur." In: Political Geography Quarterly. Vol. 9 (2), 1990, p. 146-170. 
LEITNER, Helga; PECK, Jamie; SHEPARD, Eric (eds). Contesting Neoliberalism. Urban Frontiers. New York/London: The Guilford Press, 2007.

MINISTÉRIO DAS CIDADES. Cadernos MCidades. Desenvolvimento Urbano. Brasília, 2004. Disponível em:

https://www.unc.br/mestrado/mestrado_materiais/1PoliticaNacionalDesenvolvimentoUrbano. pdf. Acesso em: 28 mar. 2018.

MENDES, Luís. "Cidade pós-moderna, gentrificação e a produção social do espaço fragmentado. In: Cadernos Metrópole. São Paulo, v. 13, n. 26, pp. 473-495, jul/dez, 2011. Disponível em: www.redalyc.org/articulo.oa?id=402837821009. Acesso em: 27 mar. 2018.

MILARÉ, Édis. Direito do ambiente: a gestão ambiental em foco: doutrina, jurisprudência, glossário. 10a ed., São Paulo: Editora Revista dos Tribunais, 2015.

OLDENBURG, Ray. Celebrating the Third Place: Inspiring Stories about the "Great Good Places" at the Heart of Our Communities. New York: Marlowe \& Company, 2000.

OSORIO, Letícia Marques. "Direito à Cidade como um Direito Humano Coletivo". In: FERNANDES, Edésio da Silva; ALFONSIN, B. Direitos Urbanísticos. Estudos Brasileiros e Internacionais. Belo Horizonte: Del Rey, 2006, p. 193-214.

PAIVA, Carlos Magno de Souza. Direito do Patrimônio Cultural: Autonomia e Efetividade. $1^{\text {a }}$ ed. Curitiba: Editora Juruá, 2015.

PECK, Jamie; TICKELL, Adam. "Neoliberalizing Space”. In: Antipode 34, 2002, p. 380404.

PREFEITURA MUNICIPAL DE BELÉM. Edital de Pregão Presencial n. 084/2017.

Disponível em: http://www.belem.pa.gov.br/licitacao/licitacao/consulta. Acesso em 29 mar. 2018.

SARGES, Maria de Nazaré. Belém: riquezas produzindo a Belle Époque: (1870-1912). Belém: Paka-Tatu, 2000.

SHAW, K. "Gentrification: what it is, why it is, and what can be done about it" In:

Geography Compass. Vol. 2, 2008, p. 1-32.

SECULT - Secretaria de Cultura do Estado do Pará. Patrimônio Cultural Tombado Belém. Disponível em:

http://www.aedmoodle.ufpa.br/pluginfile.php?file=/175047/mod_page/content $/ 12 /$ Listagem\% 20bens\%20Tombados\%20Capital\%20-\%202012.pdf. Acesso em: 06 abr. 2018.

SILVA, José Afonso da. Direito Ambiental Constitucional. São Paulo: Malheiros, 2013.

SLATER, Tom. "Gentrification of the city” In: BRIDGE, Gary; WATSON, Sophie (eds.) The New Blackwell Companion to the City. Chicester: John Wiley and Sons Ltd, 2011, p. 571-585.

THEODORE, Nick; PECK, Jamie; BRENNER, Neil. "Urbanismo Neoliberal: la ciudad y el imperio de los mercados" In: Temas Sociales (66) 1-12, 2009.

UNESCO. Convenção para Proteção do Patrimônio Mundial, Cultural Natural. Paris, 21 de novembro de 1972. Disponível em: https://whc.unesco.org/archive/convention-pt.pdf. Acesso em: 06 abr. 2018. 
VAINER, Carlos B. "Pátria, empresa e mercadoria. Notas sobre a estratégia discursiva do Planejamento Estratégico Urbano" In: ARANTES, O.; VAINER, C.; MARICATO, E. (eds.) A cidade do pensamento único: desmanchando consensos. Petrópolis: Vozes, 2000.

VÉRAS, Maura Pardini Bicudo. Trocando olhares: uma introdução à construção sociológica da cidade. São Paulo: EDUC/Studio Nobel, 2000.

VIEIRA, Flavia do Amaral; SOBRAL, Gabriela. "Direito à cidade em tempos de gourmetização: o caso do Bar do Parque em Belém do Pará”. In: Justificando. 2017.

Disponível em: http://justificando.cartacapital.com.br/2017/10/12/direito-cidade-em-temposde-gourmetizacao-o-caso-do-bar-do-parque-em-belem-do-para/. Acesso em 06 abr. 2018. 